of working women to breast feed and continuing to encourage and support breastfeeding through support groups and the health services. Health practitioners everywhere have an important part to play in promoting and supporting exclusive breastfeeding.

\section{JOSE C. MARTINES Međical Officer MARINALREA Medical Officer \\ ISABELLE DELZOYSA Research Coordinator}

Diarrhoeal Disease Control Programme,

World Health Organisation,

1211 (Geneva zz, Switzerland)

1 United States Agency for International Development. Breastfeeding: a report on AID program Washington, DC: US Agency for International Development, 1990.

2 De Zoysa I, Rea M, Martines J. Why promote breastfeeding in diarrhoeal disease control programmes? Health Policy and Planning 1991;6:371-9.
3 Brown KH, Stallings RY, Creed de Kanashiro H, Lopez de Romana G, Black RE. Effects of common illnesses on infants' energy intakes from breast milk and other foods during longitudinal
community-based studies in Huascar (Lima), Peru. Am f Clin Nutr 1990;52:1005-13. community-based studies in Huascar (Lima), Peru. Am f Clin Nutr 1990;52:1005-13. Popkin BM, Adair L, Akin JS, Black R, Briscoe J, Flieger W. Breast-feeding and diarrhea morbidity. Pediatrics 1990;86:874-82.

5 Victora CG, Smith PG, Vaughan JP, Nobre LC, Lombardi C, Teixeira AMB, et al. Infant feeding and deaths due to diarrhea: a case-control study. Am F Epidemiol 1989;129:1032-41.

6 Sachdev HPS, Krishna J, Puri RK, Satyanarayana L, Kumar S. Water supplementation in exclusively breastfed infants during summer in the tropics. Lancet 1991;337:929-33.

7 Martines JC, Ashworth A, Kirkwood, B. Breast-feeding among the urban poor in southern Brazil: reasons for termination in the first 6 months of life. Bull World Health Organ 1989;67:151-61. Akre J, ed. Infant feeding: the physiological basis. Bull World Health Organ 1989;67(suppl):1-108. 9 Almroth SG. Water requirements of breastfed infants in a hot climate. Am $\mathcal{J}$ Clin Nur 1978;31:1154-7.

10 Armelini PA, Gonzalez CF. Breastfeeding and fluid intake in a hot climate. Clin Pediatr 1979;18:424-5.

11 Goldberg NM, Adams E. Supplementary water for breast-fed babies in a hot and dry climate-not really a necessity. Arch Dis Child 1983;58:73-4.

12 Almroth S, Bidinger PD. No need for water supplementation for exclusively breast-fed infants under hot and arid conditions. Trans $R$ Soc Trop Med Hyg 1990;84:602-4.

13 Brown KH, Creed de Kanashiro H, del Aguila R, Lopez de Romana, G, Black RE. Milk consumption and hydration status of exclusively breast-fed infants in a warm climate. $\mathcal{f}$ Pediat 1986;108:677-8.

14 Canahuati J. One country's story: the PROALMA program in Honduras. In $\mathcal{f}$ Gynecol Obste 1990;31(suppl 1):17-24.

15 World Health Organisation, United Nations Children's Fund. Protecting, promoting and supporting breast-feeding: the special role of maternity services. Geneva: WHO, 1989.

\title{
Advances in the treatment of chronic heart failure
}

\author{
Two steps forward, one step back
}

Three trials have recently been published with important implications for the treatment of heart failure. They answered two questions. The first was whether enalapril, an angiotensin converting enzyme inhibitor, would improve mortality when added to conventional treatment in patients with mild or moderate heart failure; the cooperative north Scandinavian enalapril survival study CONSENSUS had already shown that angiotensin converting enzyme inhibitors increased survival in patients with severe heart failure. ${ }^{1}$ The second was whether a positive inotropic drug such as milrinone, a phosphodiesterase inhibitor, would improve mortality in patients with heart failure who were still symptomatic despite maximum conventional treatment including diuretics and an angiotensin converting enzyme inhibitor.

The studies of left ventricular dysfunction (SOLVD) were designed in two parts. ${ }^{2}$ The treatment arm included patients with heart failure who were being treated with drugs other than angiotensin converting enzyme inhibitors (usually diuretics) and had a left ventricular ejection fraction of less than $35 \% .^{3}$ Most of the cases of heart failure were due to coronary heart disease. Two thirds of the patients had no or only slight limitation of physical activity (New York Heart Association functional class I or II disease), and four out of five were male. In the prevention arm patients had a left ventricular ejection fraction of less than $35 \%$ but were asymptomatic (or nearly so) and not receiving any treatment for heart failure. The treatment arm randomised 2569 patients to either placebo or enalapril starting at a dose of 2.5 $\mathrm{mg}$ a day and increasing to a maximum of $10 \mathrm{mg}$ twice a day. ${ }^{3}$ After a mean follow up of $3^{1 / 2}$ years there were significantly more deaths in the patients treated with placebo than with enalapril (510/1284 $v$ 452/1285). This difference may have been an underestimate: nearly a quarter of the patients in the placebo group were taking angiotensin converting enzyme inhibitors after three years.

Significantly fewer patients were admitted to hospital for worsening heart failure. The benefits occurred in all subgroups regardless of plasma sodium concentration, treatment with other vasodilators, or cause or severity of heart failure. There was a suggestion that patients with no limitation of physical activity or with an ejection fraction of $30-35 \%$ may have benefited less than those with worse heart failure.
At a meeting of the American Heart Association last November the unpublished results of the prevention arm of the studies were presented. In this study 4228 patients were randomised to placebo or enalapril. Although differences in total mortality and cardiovascular mortality were not significant, the rate of admission to hospital, the frequency of progression to overt heart failure, and the incidence of myocardial infarction were lower in the patients treated with enalapril. Patients with higher ejection fractions benefited less.

The second Veterans Administration cooperative vasodilator heart failure trial (V-HeFT II) compared the effect of combined isosorbide dinitrate and hydralazine with that of enalapril ( $5 \mathrm{mg}$ initially, increasing to $20 \mathrm{mg}$ daily) in $804 \mathrm{men}$ with a mean age of $61 .^{4}$ The criteria for inclusion were cardiac dysfunction and reduced exercise tolerance despite optimal treatment with diuretics and digoxin. Half the patients had slight symptoms (New York Heart Association functional class II). The mean oxygen consumption was $14 \mathrm{ml} / \mathrm{kg} / \mathrm{min}$ and $30 \%$ drank alcohol. Mortality at two years was $25 \%$ in patients treated with isosorbide dinitrate and hydralazine, significantly higher than the mortality of $18 \%$ in patients treated with enalapril. The first Veterans Administration heart failure trial (V-HeFT I) had previously shown that the combination of nitrates and hydralazine reduced mortality compared with placebo. ${ }^{5}$ An identical outcome of both Veterans Administration trials with the same entry criteria and this combination of drugs allowed a comparison of the placebo group from the first trial and the enalapril group from the second trial. Mortality at two years was $34 \%$ in patients treated with placebo compared with $18 \%$ in patients treated with enalapril.

The patients admitted to the second Veterans Administration trial probably had more severe heart failure than those in the studies of left ventricular dysfunction. The average age of patients in both trials was below that of patients with heart failure in a population study, ${ }^{6}$ suggesting some selection of patients had occurred, possibly related to attendance at hospital. Surprisingly, neither study stated the dose of diuretics received by patients. In the second Veterans Administration trial mortality from sudden death was reduced, whereas in the studies of left ventricular dysfunction and the 
cooperative north Scandinavian enalapril survival study death due to progression of heart failure was reduced. This difference may be related to the methods of classifying death, a notoriously difficult matter.

Both studies had limitations. Patients with ejection fractions of over $35 \%$ and patients with abnormal renal function (serum creatinine concentration over $177 \mu \mathrm{mol} / \mathrm{l}$ ) were excluded from studies of left ventricular dysfunction. Given the average age of the patients in the studies, the results may not be generalisable to an elderly population. Side effects were common, but only dizziness and cough were more common in the group treated with enalapril in the studies of left ventricular dysfunction and even this difference was small. After a first dose of $2.5 \mathrm{mg}$ enalapril only $0.2 \%$ of 7402 patients were excluded from the trial for worsening renal function and $2 \cdot 2 \%$ because of symptomatic hypotension. Treatment was begun in hospital for only $1 \cdot 2 \%$ of patients.

Thus concerns about renal function and syncope, which have made British prescribers reluctant to use angiotensin converting enzyme inhibitors, seem unfounded when treatment is begun at a low dose. Importantly, patients were begun on enalapril after their condition had been stabilised with a diuretic. Treating heart failure with an angiotensin converting enzyme inhibitor alone is not particularly effective, ${ }^{7}$ and there is little information on the initiation of treatment of heart failure with a diuretic and an angiotensin converting enzyme inhibitor at the same time. Both studies of left ventricular dysfunction used enalapril; whether the benefits in terms of mortality are a class effect of all angiotensin converting enzyme inhibitors or are limited to enalapril is unknown. Benefit in terms of reducing the progression of heart failure has recently been reported with captopril $(25 \mathrm{mg}$ twice a day) in a single centre trial in 170 patients. ${ }^{8}$

Why enalapril improves mortality as well as symptoms remains unclear. The effect is unlikely to be attributable solely to its vasodilatory action as other vasodilators do not have this effect. Inhibition of angiotensin converting enzyme may affect other biochemical pathways, act synergistically with diuretics in the kidney, prevent the activation of the renin-angiotensin pathway by diuretics, modify remodelling of the enlarging heart, prevent the development of fibrosis, or affect changes in the peripheral circulation.

By contrast, the prospective randomised milrinone survival evaluation trial was a disappointment. The trial was stopped early by the monitoring committee. ${ }^{9}$ Milrinone ( $40 \mathrm{mg}$ daily) was given to 561 patients and placebo to 527 ; after a median follow up of 6 months significantly more patients treated with milrinone had died. Milrinone was associated with more admissions to hospital and more cardiovascular events. The effects were seen in all subgroups, but the mortality was highest in those with the most severe heart failure.

How do these trials affect the treatment and management of heart failure? Heart failure is common, affecting about one in 250 people, ${ }^{610}$ and it causes substantial long term morbidity and mortality. ${ }^{10-12}$ The syndrome is characterised by symptoms, left ventricular dysfunction, and sodium and water retention. The primary role of diuretics in the management of acute and chronic heart failure remains unchallenged. Digoxin is still widely used in addition to diuretics in both patients with atrial fibrillation and those in sinus rhythm, ${ }^{1314}$ although the benefit of digoxin in patients in sinus rhythm is small. $^{13}$

The increased mortality with milrinone may be a class effect of phosphodiesterase inhibitors due to increased concentrations of cyclic AMP or calcium in the myocyte, which predisposes to arrhythmias. ${ }^{9}$ Alternatively, it might result directly from excessive positive inotropy, leading to biochemical derangement of an already compromised myocardium. If this was so, then all positive inotropic drugs, including digoxin, might have this effect. The National Institutes of Health in the United States is currently running a large trial to determine the effect of digoxin on mortality in chronic heart failure.

The implications of the two trials of enalapril are clear. Angiotensin converting enzyme inhibitors should be added to the treatment of most patients with chronic heart failure whose condition has already been stabilised with diuretics with or without digoxin unless contraindications are present. These contraindications are pregnancy, angio-oedema, collagen vascular disease, bilateral renal artery stenosis, and symptomatic hypotension.

Care is needed in patients receiving high doses of diuretics who may be volume depleted or have renal failure. The problems of renal impairment and syncope, particularly after the first dose, which have previously been regarded as a drawback, almost certainly relate to the excessive initial dose used several years ago. Renal failure was not reported in studies of left ventricular dysfunction. The preliminary results from the prevention arm of the studies of left ventricular dysfunction provide reassurance for this strategy. Whether and how angiotensin converting enzyme inhibitors should be used after myocardial infarction or in asymptomatic patients with isolated left ventricular dysfunction is still uncertain.

Not all problems are resolved by these studies. The mortality from heart failure remains high $-35 \%$ at four years - and other treatments will be needed. Meanwhile, the treatment of heart failure in the United Kingdom should be given higher priority in the allocation of health resources: not often have new treatments been shown to improve both the quality and the length of life.

PHILIP A POOLE-WILSON Professor of Cardiology DAVID LINDSAY

National Heart and Lung Institute, Research Registrar

Royal Brompton Hospital,

London SW3 6LY

1 CONSENSUS Trial Study Group. Effects of enalapril on mortality in severe congestive heart failure. Results of the cooperative north Scandinavian enalapril survival study (CONSENSUS). N Engl f Med 1987;316:1429-35.

2 SOLVD Investigators. Studies of left ventricle dysfunction (SOLVD)-rationale, design, and methods: two trials that evaluate the effect of enalapril in patients with reduced ejection function. Am 7 Cardiol 1990;66:313-22.

3 SOLVD Investigators. Effect of enalapril on survival in patients with reduced left ventricular ejection fractions and congestive heart failure. $N$ Engl f Med 1991;325:293-302.

4 Cohn JN, Johnson G, Ziesche S, Cobb F, Francis GS, Tristani F, et al. A comparison of enalapril with hydralazine-isosorbide dinitrate in the treatment of chronic congestive heart failure. $N$ Engl with hed 1991;325:303-10.

5 Cohn JN, Archibald DG, Ziesche S, Franciosa JA, Harston WE, Tristani FE, et al. Effect of vasodilator therapy on mortality in chronic congestive heart failure. Results of a Veteran vasodilator therapy on mortality in chronic congestive heart failure

6 Parameshwar J, Shackell MM, Richardson A, Poole-Wilson PA, Sutton GC. Prevalence of heart failure in north-west London-a general practice survey. Brf Gen Pract (in press).

7 Richardson A, Bayliss J, Scriven AJ, Parameshwar J, Poole-Wilson PA, Sutton GC. Double-blind comparison of captopril alone against frusemide plus amiloride in mild heart failure. Lancet 1987;ii:709-11

8 Kleber FX, Niemöller L, Doering W. Impact of converting enzyme inhibition on progression of chronic heart failure: results of the Munich Mild Heart Failure Trial. Br Heart $\mathcal{f}$ 1992;67:289-96. 9 Packer M, Carver JR, Rodefeffer RJ, Ivanhoe RJ, DiBianco R, Zeldis SM, et al. Effect of milrinone on mortality in severe chronic heart failure. $N$ Engl f Med 1991;325:1468-75.

10 Smith WM. Epidemiology of congestive heart failure. Am f Cardiol 1985;55:3-8A.

11 Poole-Wilson PA. Chronic heart failure: cause, pathophysiology, prognosis, clinical manifestations, investigations. In: Julian DG, Camm AJ, Fox KF, Hall RJC, Poole-Wilson PA, eds. Diseases of the heart. London: Ballière-Tindall, 1989:24-36.

12 Parameshwar J, Poole-Wilson PA, Sutton GC. Heart failure in a district hospital. $\mathcal{F} R$ Coll Physicians Lond (in press).

13 Poole-Wilson PA, Robinson K. Digoxin-a redundant drug in the treatment of congestive heart failure. Cardiovasc Drugs Ther 1989;2:733-41.

14 Jaeschke R, Oxman AD, Guyatt GH. To what extent do congestive heart failure patients in sinus rhythm benefit from digoxin therapy? A systematic overview and meta-analysis. Am $\mathcal{F}$ Med $1990 ; 88: 279-86$ 2 ก

$$
\text { N }
$$

